\title{
Effect of liver ischemic preconditioning in cirrhotic rats submitted to hepatic ischemia/reperfusion injury ${ }^{1}$
}

\author{
Efeito do pré-condicionamento isquêmico hepático submetidos \\ a lesão de isquemia/reperfusão do fígado
}

\author{
Eduardo Garcia Pacheco², Maria Cecília Jordani Gomes ${ }^{3}$, Gustavo Ribeiro Rodrigues ${ }^{4}$, Walter Campos ${ }^{4}$, Rafael Kemp$^{5}$, \\ Orlando de Castro e Silva ${ }^{6}$
}

1. Study performed in the Laboratory of Biochemistry of Liver Transplantation Unit of Division of Gastroenterology of the Department of Surgery and Anatomy, Ribeirão Preto Faculty of Medicine - University of São Paulo (FMRP - USP), Brazil.

2. Fellow PhD degree, Assistant of the Liver Transplant Program of the Division of Gastroenterology of the Department of Surgery and Anatomy, (FMRP-USP), Brazil.

3. Biochemist of Laboratory of Biochemistry of Liver Transplantation Unit of Division of Gastroenterology of the Department of Surgery and Anatomy, (FMRP-USP), Brazil.

4. PhD, Assistant of the Liver Transplant Program of Division of Gastroenterology of the Department of Surgery and Anatomy, (FMRPUSP), Brazil.

5. MD, Assistant of Division of Gastroenterology of the Department of Surgery and Anatomy, (FMRP-USP), Brazil.

6. Full Professor, Head of Division of Gastroenterology of the Department of Surgery and Anatomy, Coordinator of the Liver Transplant Program, (FMRP-USP), Brazil.

\begin{abstract}
Purpose: The main aim of this study was to determine the influence of ischemic preconditioning (IPC) on rat liver cirrhosis. Methods: Cirrhosis was induced in Wistar rats by occlusion of the hepatic duct. The animals were divided into four groups of six animals each: non-cirrhotic group (simulated operation only), cirrhotic control group (simulated operation in cirrhotic rats), I/R group (40-minute ischemia without IPC), and IPC group (cirrhotic rats with ischemia, previously submitted to IPC). The IPC procedure consisted of partial hepatic ischemia for five minutes, followed by 10 minutes of reperfusion. In the case of the IPC group, the animals were submitted to liver ischemia for 40 minutes after the preconditioning procedure, followed by 2 hours of reperfusion. Blood samples were collected for measurement of serum aminotransferases (ALT and AST). The respiratory control ratio (RCR), the mitochondrial membrane potential (MMP), and malondialdehyde (MDA) values in the hepatic tissue were analyzed. Nonparametric statistical analysis was used and a value of $p<0.05$ was considered statistically significant. Results: Ischemia did not induce significant increase in ALT and AST levels. MDA values were significantly higher in cirrhotic animals. MMP did not significantly change in cirrhosis and liver ischemia. Mitochondrial RCR decreased in liver cirrhosis, accentuated upon liver ischemia, and did not significantly change with IPC. Conclusion: Ischemic preconditioning does not protect the liver from hepatic injury induced by the ischemia/ reperfusion process. Key words: Liver Cirrhosis. Hepatic Ischemia. Ischemic Preconditioning.
\end{abstract}

\section{RESUMO}

Objetivo: O objetivo deste estudo foi determinar a influência do pré-condicionamento isquêmico (IPC) em fígados de ratos cirróticos. Métodos: A cirrose hepática foi induzida em ratos Wistar machos (250 a $300 \mathrm{~g}$ ) por oclusão, durante 30 dias, do ducto hepático comum.A seguir, os animais cirróticos foram divididos em três grupos de seis; Grupo controle cirrótico (operação simulada para isquemia/reperfusão/pré-condicionamento), Grupo $\mathrm{I} / \mathrm{R}$, isquemia de 40 minutos sem précondicionamento (IPC) e grupo IPC com isquemia precedida por IPC. O IPC consistiu de uma isquemia parcial por cinco minutos, seguida por 10 minutos de reperfusão. No grupo IPC, após o pré-condicionamento, os animais foram submetidos à isquemia hepática de 40 minutos seguida de 2 horas de reperfusão. Foram colhidas amostras de sangue para dosagem sérica de aminotransferases (ALT e AST). Razão de controle respiratório (RCR), potencial de membrana das mitocôndrias (PMM) e dosagem de malondialdeído (MDA) foram analisadas no tecido hepático. Analise estatística não paramétrica foi utilizada com nível de significância de 5\% para as comparações entre grupos.Resultados: A isquemia não induziu aumento significativo das aminotransferases. Houve aumento significativo de MDA nos animais cirróticos.O PMM não se alterou significativamente na cirrose e na isquemia hepática. A RCR mitocondrial diminuiu na cirrose hepática e acentuou-se com a isquemia do fígado e não se alterou significativamente com o IPC. Conclusão: $\mathrm{O}$ pré-condicionamento isquêmico não protegeu o fígado das lesões hepáticas induzidas pelo processo de isquemia/reperfusão.

Descritores: Cirrose Hepática. Pré- Condicionamento Isquêmico. Isquemia. Reperfusão 


\section{Introduction}

Hepatocellular carcinoma (HCC) is one of the commonest primary tumors of the liver and is certainly related to (i) the anarchic way in which hepatocytes regenerate in cirrhotic livers, (ii) the increased replication conditions of liver parenchymal cells, and (iii) the frequent activation of proto-oncogenes ${ }^{1}$. Around 15 to $20 \%$ of the patients with $\mathrm{HCC}$ will benefit from tumor resection or alcoholization, as well as liver orthotopic transplantation ${ }^{2}$. The efficacy of liver resection depends on the regenerative capacity of the remnant liver, and it is directly related to the continuous energy flow provided by the mitochondria. Bleeding control during liver resection is essential because, within certain limits, patients withstand prolonged periods of ischemia better than they stand great hemorrhages and the subsequent transfusions ${ }^{2}$. Nevertheless, it is known that, although ischemia avoids or minimizes bleeding throughout surgery, it induces different levels of hepatocellular damage and many of these lesions develop during reoxygenation induced by reperfusion, this effect being more pronounced in liver cirrhosis. Partial hepatic inflow occlusion (PHIO) is an effective and simple technique to control blood loss from the raw surface during hepatic parenchymal transaction, and it has been widely used during hepatectomy. However, PHIO may also result in hepatic ischemic-reperfusion (I/R) injury, especially in the case of cirrhosis. It is generally accepted that the cirrhotic liver is particularly sensitive to ischemia. Although warm ischemia for cirrhotic liver should not exceed $30 \mathrm{~min}$, prolonged HIO might cause dysfunction of the remnant liver, which is a major risk factor associated with postoperative morbidity and mortality ${ }^{3}$. Various methods such as the use of drugs, hypothermia, and ischemic preconditioning (IPC) have been used in order to protect the liver from injury induced by ischemia/reperfusion $(I / R)$. The term ischemic preconditioning refers to brief periods of ischemia followed by a short reperfusion period before prolonged ischemia. The role IPC plays in increased tolerance to ischemia has been demonstrated in a number of organs such as the heart, brain, bone marrow, skeletal muscle, retina, kidneys, intestines, and liver. Clavien et al. ${ }^{4}$ carried out the first clinical study involving IPC. Their clinical results were similar to the experimental ones, and they demonstrated the presence of decreased aminotransferase serum levels and apoptosis of sinusoidal cells. Peralta et $a l .{ }^{5}$ have demonstrated the similar action mechanisms of nitric oxide (NO) and exogen adenosine, as well as the role of PCI in inducing tolerance to $\mathrm{I} / \mathrm{R}$, corroborating the hypothesis that activation of A2 adenosine receptors and NO production are the main processes induced by PCI. It is believed that mediators such as NO, adenosine, prostacyclins, and bradicinines promote significant previous protection against I/R. Adenosine and NO are synthesized in the vascular endothelium and released into the intersticial perivascular compartment during $\mathrm{I} / \mathrm{R}^{6}$. This mechanism has not yet been established and, to the best of our knowledge, it has not been described in rats with cirrhotic liver. We know that liver cirrhosis is characterized by a diffuse fibrotic process that is accompanied by nodular regeneration, derangement of the architecture, obstruction of the free portal venous flux, and reduction in the ability of parenchymal synthesis, factors that make the cirrhotic liver less tolerant to ischemia and reperfusion. ${ }^{6}$ Therefore, the aim of the present study is to evaluate the effect of IPC in cirrhotic livers submitted to $\mathrm{I} / \mathrm{R}$.

\section{Methods}

Male Wistar rats $(n=44)$ weighing $240-300$ g were employed in this work, according to the guidelines of the Ethics Committee for Animal Experimentation of the Ribeirão Preto Faculty of Medicine, University of São Paulo. The animals were divided into 4 groups: Control group: noncirrhotic, $\mathrm{n}=6$; cirrhotic group, $\mathrm{n}=6$; I/R group $\left(\mathrm{I} 40^{\prime}\right), \mathrm{n}=$ 6; IPC group (IPC/I 40'), $\mathrm{n}=6$, where I stands for ischemia, $\mathrm{R}$ for reperfusion, and IPC for ischemic preconditioning. All the groups were submitted to reperfusion (R) for 2 hours. The anaesthetic technique used in this work was ether inhalation in a closed container, and anaesthesia was maintained by means of a cotton soaked with ether, which was kept near the animal's airway throughout the surgical process.

\section{- $1^{\text {st }}$ Phase}

Induction of secondary biliar cirrhosis: The anaesthetized animal was placed in supine position and submitted to median laparotomy, exposing the viscera for identification of the biliar duct. By means of an anatomical clip, ligature of the biliar duct was carried out with a prolene 5-0 thread, as previously described ${ }^{7}$. The abdominal wall was closed in two planes with absorbable thread, the animal was taken to the animal house again and kept there for 30 days, until cirrhosis took place.

\section{- $2^{\text {nd }}$ Phase}

Experiment with or without IPC, followed by $I / R$ : Control group - non-cirrhotic: normal rats submitted to simulated operation for ischemic preconditioning and ischemia.

Control Group - cirrhotic: cirrhotic rats submitted to simulated operation for ischemic preconditioning and ischemia/reperfusion.

I/R Group: cirrhotics rats submitted to laparotomy and exposure of the hepatic pedicle without IPC. The pedicle was then clamped for 40 minutes (ischemia).

IPC Group: cirrhotics rats submitted to ischemic preconditioning, identification of the hepatic pedicle (which was clamped with a delicate clip for five minutes), followed by reperfusion for 10 minutes. The hepatic pedicle was then clamped for another 40 minutes (ischemia).

After this phase, the abdominal walls of all the animals were closed in a single plane, and the awoken animals awaited 120 minutes of reperfusion. 


\section{- $3^{\text {rd }}$ Phase}

Sample collection and animal euthanasia: The animals were anaesthetized again and submitted to a new infra-umbilical semi-oval laparotomy, which exposed all the abdominal cavity. Blood was collected by puncture of the inferior vena cava, and partial hepatectomy of the median lobe was accomplished, followed by animal euthanasia.

Blood samples were used to measure serum aminotransferase levels (ALT and AST). Mitochondria were extracted from the material resulting from the partial hepatectomy and they were used for determination of mitochondrial respiration and membrane potential. The mitochondria were also employed for the preparation of a homogenate that was used to determine malondialdehyde (MDA), which is generated mainly during fatty acid peroxygenation and reflects the concentration of oxygen free radicals.

\section{Preparation of mitochondria and oxygen} consumption assays

Isolation of liver mitochondria was performed by differential centrifugation ${ }^{8}$. Mitochondrial oxygen consumption was analyzed polarographically by means of a home-made oxygraph equipped with a Clarck oxygen electrode, and the respiratory parameters were determined according to an established procedure? ${ }^{9}$. Succinate $(5 \mathrm{mM})$ was used as the oxidizable substrate in a medium $(1.4 \mathrm{~mL})$ containing $125 \mathrm{mM}$ sucrose, $65 \mathrm{mM} \mathrm{KCl}, 1 \mathrm{mM} \mathrm{MgCl}, 2 \mathrm{mM}$ $\mathrm{KH}_{2} \mathrm{PO}_{4}, 0.1 \mathrm{mM}$ EGTA, and $10 \mathrm{mM}$ Hepes-KOH, pH 7.4. Two miligrams of mitochondrial protein were used. State 3 respiration was induced with $400 \mathrm{nmol}$ ADP, and state 4 respiration (basal mitochondrial respiration) was determined after phosphorylation of the additional ADP ${ }^{9}$. Determination of the ratio between the state 3 and state 4 rates (respiratory control ratio - RCR), which represents the coupling between electron transport and oxidative phosphorylation, was carried out. The mitochondrial protein content was determined by the biuret method.

\section{Mitochondrial Membrane Potential (MMP)}

MMP was monitored spectrofluorimetrically using 5 $\mathrm{mM}$ safranine-O as indicator and an SLM-Aminco, Bowman, series 2, luminescence spectrophotometer operating at 495/ $586 \mathrm{~nm}$ excitation/emission wavelength pair $^{10}$. Assays were performed in an incubation medium containing $200 \mathrm{mM}$ sucrose, $1 \mathrm{mM} \mathrm{MgCl}_{2}, 2.5 \mathrm{mM} \mathrm{NaH}_{2} \mathrm{PO}_{4}$, and $10 \mathrm{mM}$ Hepes$\mathrm{KOH}$, at $\mathrm{pH}$ 7.4. Mitochondria were energized by $5 \mathrm{mM}$ sodium succinate. The membrane potential variation was expressed in $\mathrm{mV}$, as usual.

\section{Determination of Malondialdehyde (MDA)}

Determination of MDA levels in the hepatic tissue was carried out by means of a kit purchased from Calbiochem, using a colorimetric reaction read at $586 \mathrm{~nm}$.
Statistical Analysis: Results obtained with the groups studied here were analyzed and compared by Kruskal-Wallis and Mann-Whitney non-parametrical tests. Differences were considered significant when $\mathrm{p}<0.05$.

\section{Results}

The AST values were similar among the cirrhotic groups $(p>0.05)$, and higher in the non-cirrhotic control group $(p<0.05)$, Figure 1. The ALT values were significantly higher in the cirrhotic groups when compared with the non-cirrhotic groups $(p<0.05)$, and similar within the cirrhotic groups $(p>0.05)$. No statistically significant difference was found in the MDA values among the cirrhotic rats $(p>0.05)$, except in the case when the latter were compared with the noncirrhotic control group $(\mathrm{p}<0.05$, Figure 3$)$. As can be seen in this Figure 4, there is no significant statistical difference between the MMP values among the studied groups ( $p>0.05$ ), control vs cirrhotic groups (sham,IR, IPC). As shown in Figure 5, RCR values were lower in the cirrhotic groups than in the non-cirrhotic control group. Control vs cirrhotic groups (sham,IR, IPC) $(\mathrm{p}<0.05)$.

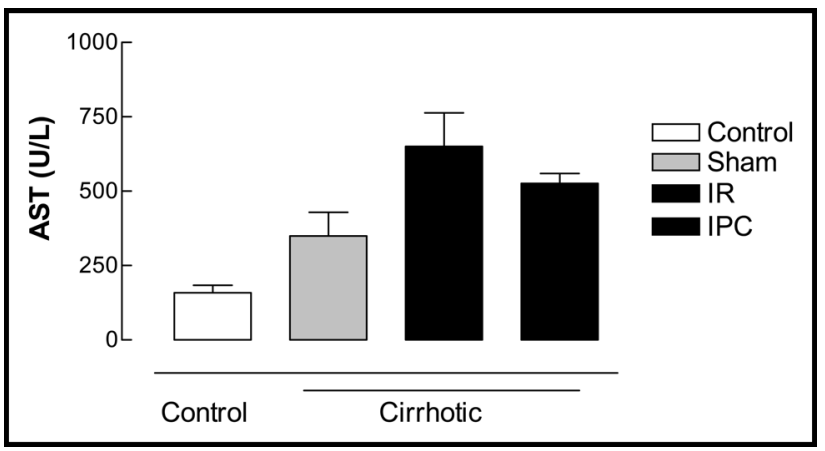

FIGURE 1 - AST values in the different groups studied in this work. Control vs cirrhotic groups (sham, IR, IPC) $\mathrm{p}<0.05$.

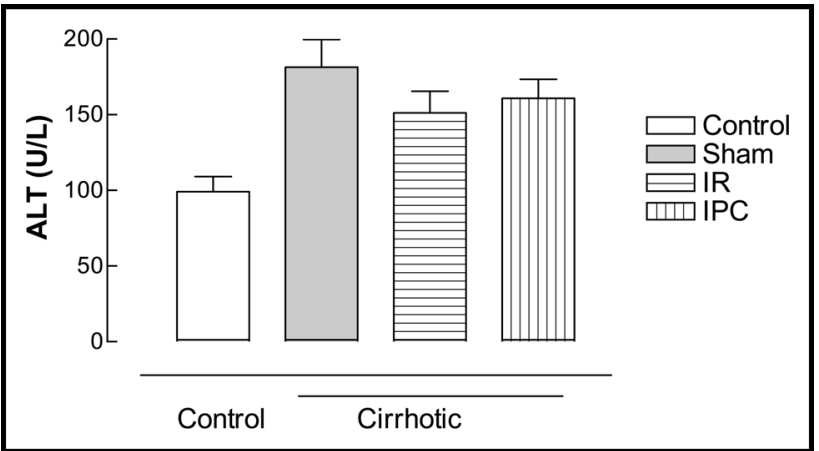

FIGURE 2 - ALT values in the different groups studied in this work. Control vs cirrhotic groups (sham, IR, IPC) $\mathrm{p}<0.05$. 


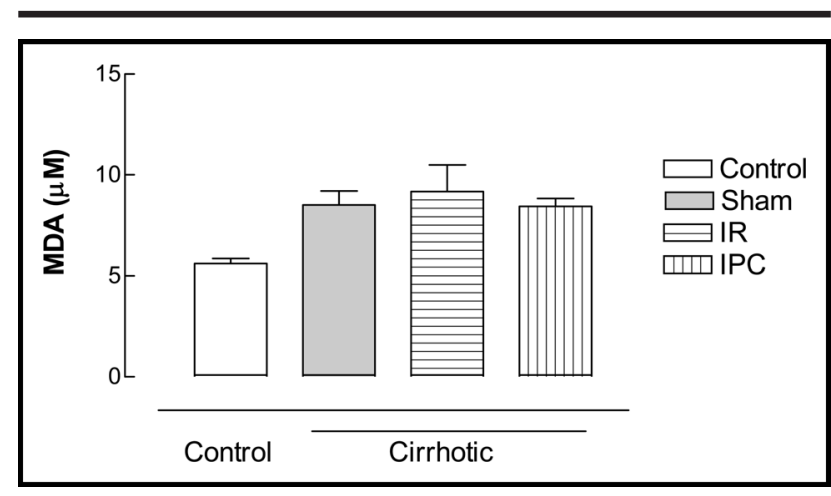

FIGURE 3 - MDA values in the groups studied in this work. Control vs cirrhotic groups (sham, IR, IPC) $\mathrm{p}<0.05$.

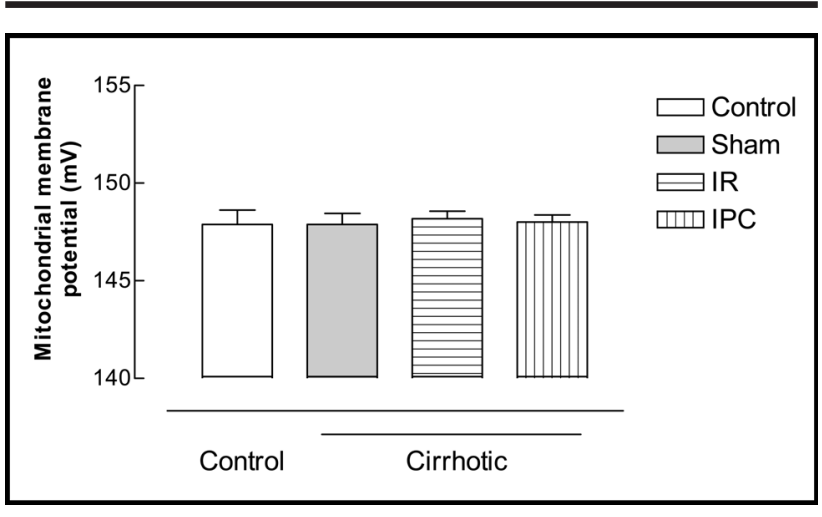

FIGURE 4 - MMP values in the studied groups. Control vs cirrhotic groups (sham,IR, IPC).

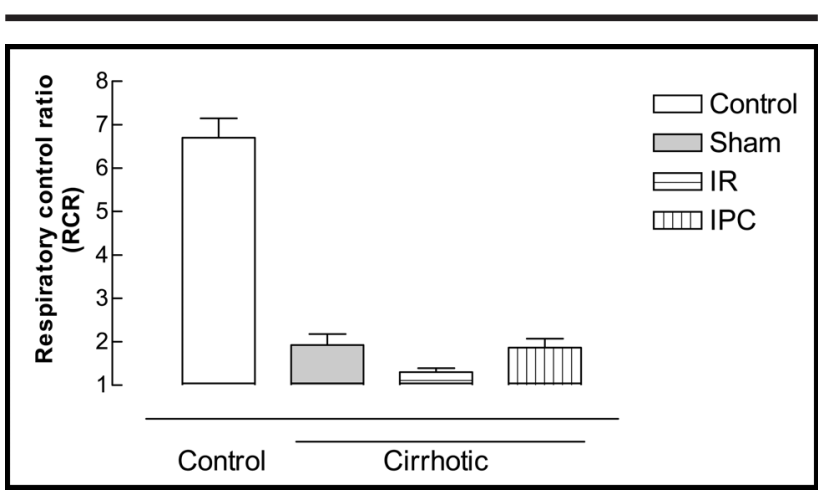

FIGURE 5 - RCR values in the three studied groups. Control vs cirrhotic groups (sham, IR, and IPC).

\section{Discussion}

Hemmorrhage is the major lethal factor associated with hepatic resection. Hemostasis can be achieved by PHIO, and this maneuver, which has the lowest hemodynamic effect, has been widely used in liver surgery ${ }^{11,12}$. However, PHIO could also result in liver I/R injury, which is one of the major factors leading to postoperative liver dysfunction. It is well known that the cirrhotic liver is very vulnerable to ischemic injury so, although warm ischemia for cirrhotic liver should not exceed $30 \mathrm{~min}$, and despite the fact that the majority of liver resections could be finished within this time limit by using diathermy and by crushing the hepatic tissue with an artery forceps, the deleterious effect of ischemia cannot be neglected. In order to minimize liver I/R injury, intermittent hepatic inflow occlusion (iHIO) has been used in $\mathrm{HCC}$ resection ${ }^{13,14}$. However, massive bleeding might result from iHIO during the reperfusion period, which might increase the need for blood transfusion and the possibility of postoperative morbidity and tumor recurrence. In the liver of normal rats, IPC promotes increased circulation and reduces the adherence of sinusoidal leucocytes after I/R. Moreover, IPC inhibits the apoptosis of hepatic cells, conferring the liver greater resistance to $\mathrm{I} / \mathrm{R}$ injury. It has been reported that IPC is an effective protective strategy in several animal models ${ }^{15}$. In fact, studies have demonstrated that ischemic preconditioning is a protective strategy against hepatic ischemia in humans, but its use as a protective factor against $\mathrm{I} / \mathrm{R}$ in cirrhotic liver has not yet been established. ${ }^{13,14,15}$. In the present study we observed increased MDA levels in the cirrhotic animals, which gives evidence that cirrhosis proceeds with considerable levels of lipoperoxidation, as reported in the literature for carbon tetrachloride-induced cirrhosis and secondary biliar cirrhosis ${ }^{15}$. This probably occurs because of hepatocellular derangement and fibrogenesis, which can be perpetuated by the lipoperoxidation products malonaldehyde and malondialdehyde ${ }^{15}$. A component due to functional ischemia also has to be considered as a factor probably responsible for the release of endogen lipases and lipoperoxidation ${ }^{7,15}$. This is because there is a significant decrease in the portal flow, as observed in the case of chronic cholestasis and experimental secondary biliar cirrhosis ${ }^{7}$. We also verified that ischemia and reperfusion were not enough to accentuate lipoperoxidation under our experimental conditions. This finding deserves further studies that will surely promote a better understanding of this issue. As for the aminotransferases, there were no significant changes in the AST and ALT serum levels of the cirrhotic rats in any of the studied groups. It is known that these enzymes indicate the occurrence of major changes, and they are found in normal or slightly increased levels in the case of cirrhosis ${ }^{4}$. The period of induced ischemia used in this study was not enough to increase AST and ALT serum levels significantly, despite the fact that hepatocellular damage took place, as shown by the significant reduction in mitochondrial function as evaluated by the RCR. On the other hand, it must be taken into account that there probably was no alteration in membrane potential in any of the studied groups. This suggests that, despite lipoperoxidation, the membrane was kept untouched, thus preventing significant aminotransferases transfer to the plasma. This is yet another point that lends itself to future studies. In turn, IPC was not able to prevent or attenuate I/R damage within the 40 minutes of ischemia and reperfusion, under the experimental conditions employed herein. 


\section{References}

1. Lima RS, Jordani MC; Souza MEJ, Picinato MANC, Franco CFF, Castro e Silva O Jr. Eficácia do pré-condicionamento isquêmico na proteção das lesões de isquemia e reperfusão hepática. Acta Cir Bras. 2000; 2:23-4.

2. Malhi H, Gorla GR, Irani AN, Annamaneni P, Gupta S. Cell transplantation after oxidative hepatic preconditioning with radiation and ischemia-reperfusion leads to extensive liver repopulation. Proc Natl Acad Sci. 2002; 99:13114-9.

3. Ajamieh H, Merino N, Candelario-Jalil E, Menendez S, Martinez-Sanchez G, Re L, Giuliani A, Leon OS. Similar protective effect of ischaemic and ozone oxidative preconditionings in liver ischaemia/reperfusion injury. Pharmacol Res. 2002; 45:333-9.

4. Clavien PA, Tdav S, Sindram D, Bentley C. Protective effects of ischemic preconditioning for liver resection performed under inflow occlusion in humans. Ann Surg. 2000; 232:155-62.

5. Peralta C, Hotter G, Closa D, Prats N, Xaus C, Gelpí E, Roselló-Catafau J. The protective role of adenosine in inducing nitric oxide synthesis in rat liver ischemia preconditioning is mediated by activation of adenosine A receptors. Hepatology. 1999; 29:126-32.

6. Hardi KJ; Tancheroen S, Shulkers A. Comparison of continous versus intermittent ischemia-reperfusion during liver resection in an experimental model. Br J Surg. 1995; 82: 833-6.

7. Roselino JES, Castro e Silva O, Ceneviva R. Lack of control of liver gluconeogenesis in cholestatic rats with reduced portal blood flow. Hepatology. 1992:16:1055-60.
8. Pedersen PL, Greenawalt JW, Reynafarje B, Hullihen J, Deccker GL, Soper JW, Bustamente E. Preparation and characterization of mitochondria and submitochondrial particles of rat liver and liver-derived tissues. Meth Cell Biol. 1978; 20:411-81.

9. Souza MEJ, Polizello ACM, Uyemura SA, Castro e Silva OJr., Curti C. Effect of fluoxetine on rat liver mitochondria. Bioch Pharmacol. 1994; 48: 535-41.

10. Jordani MC, Santos AC, Prado IMR, Uyemura SA, Curti C. Flufenamic acid as an inducer of mitochondrial permeability transition. Mol Cell Biochem. 2000; 210: 153-8.

11. Huguet C, Gavelli A, Chieco PA, Bona S, Harb J, Joseph JM, Jobard J, Gramaglia M, Lasserre M. Liver ischemia for hepatic resection: where is the limit? Surgery. 1992; 111:251-9

12. Man K, Fan ST, Ng IO, Lo CM, Liu CL. Wong J. Prospective evaluation of Pringle maneuver in hepatectomy for liver tumors by a randomized study. Ann Surg. 1997; 226: 704-13

13. Selzner N, Rudiger H, Graf R, Clavien PA. Protective strategies against ischemic injury of the liver. Gastroenterology. 2003; 125: 917-36

14. Belghiti J, Noun R, Malafosse R, Jagot P, Sauvanet A, Pierangeli F, Marty J, Farges O. Continuous versus intermittent portal triad clamping for liver resection: a controlled study. Ann Surg. 1999; 229: 369-75.

15. Andiran F, Kilinc K, Renda N, Ayhan A, Tanyel FC. Lipid peroxidation and extracellular matrix in normal and cirrhotic rat livers following 70\% hepatectomy. Hepatogastroenterology. 2003;50:805-8.
Correspondence:

Orlando de Castro e Silva Jr.

Rua Campos Salles, 809/9 andar

14015-110 Ribeirão Preto - SP Brazil

orlando@ffmrp.usp.br
Conflict of interest: none Financial source: CNPq and FAPESP

\section{How to cite this article:}

Pacheco EG, Gomes MCJ, Rodrigues GR, Campos W, Kemp R, Castro e Silva O. Effect of liver ischemic preconditioning in cirrhotic rats submitted to ischemia/reperfusion injury. Acta Cir Bras. [serial on the Internet] 2006;21 Suppl 1. Available from URL: http://www.scielo.br/acb 